Around these two major axes are clustered numerous other areas of special concern. Two such are currently battlefields on which wars are being fought with victory for psychiatry in sight on one and defeat on the other. The former is leading to the gradual shrinkage of the power of attorneys to encourage juries to find vast sums for plaintiffs in malpractice claims. These claims have not been as outrageous in psychiatry as in some other specialties but are still sufficient that the average malpractice insurance premium for a policy now offered by the American Psychiatric Association is $\$ \mathbf{5 , 0 0 0}$ per annum. Tort reform initiatives in several states launched by powerful political and fiscal manoeuvring by state medical associations have been won in many areas and are now beginning to take effect.

The defeat is one that appears to be imminent in the battle with the clinical psychologists. For some time they have provided psychotherapy and have done so at lower rates than are current among psychiatrists. Now the psychologists are moving in the courts to seek the additional right to have hospital admitting privileges and prescription writing powers. Demise rather than mere dissent appears to be looming on the horizon!
Does all this seem sufficient to account for the 'over-determined' look about most American psychiatrists I know? And there are other matters of note: the shortage of nurses, 'managed care plans', the impact of foreign medical graduates, the dementia and other psychiatric aspects of AIDS and the growing trend toward sub-specialisation within psychiatry. But those are issues on both sides of the Atlantic.

\section{References}

Crammer, J. L. (1986) An English psychiatrist in Ontario. Bulletin of the Royal College of Psychiatrists, 10, 315-316. EdTORIAl (1988) American Psychoanalytical Association Newsletter, 23, 2.

GoLD, M. S. (1987) The Good News about Depression. New York: Villard Books.

MERRILL, T. S. (1988) APA considers results of fee study "tragic" for psychiatry. Clinical Psychiatry News, 11, 1. SzMuxLer, G. (1987) Foreign report: Psychiatry in Australia. Bulletin of the Royal College of Psychiatrists, 11, 258-260.

A full list of references is available on request from the author.

\title{
Conference report
}

\section{Casting out demons?*}

\section{A. E. Thompson, SHO in Psychiatry, Shotley Bridge General Hospital, Shotley Bridge, Consett DH8 ONB (correspondence); and P. F. MAHONEY, SHO in Paediatrics, Royal Victoria Infirmary, Newcastle upon Tyne NE1 4LP}

A one day conference on possession and religious psychosis drew clergymen, doctors and other health care workers from across England and Scotland. It

*A report on the conference held on 26 April 1989 at the Roker Hotel, Sunderland. was organised by Sunderland Health Authority and papers were presented by churchmen and by psychiatrists, under the chairmanship of John Cox, Professor of Psychiatry at Keele University.

The Reverend Canon Anthony Duncan, the Vicar of Whitley Mill in Northumberland, opened the 
proceedings by putting the concept of possession into a historical perspective. He explained that from early times the Christian church had acknowledged the presence of the spirit world and man's vulnerability to evil. For many centuries ceremonies of baptism had incorporated exorcism prior to blessing. During the Middle Ages great emphasis was placed on categorising the forces of evil into a demonic hierarchy, all part of an unhealthy preoccupation with the occult. However, when the Christian church in Britain divided during the reformation, the new Anglican churches largely rejected the concept of possession.

Canon Duncan described two different views of possession. Some men accept the influences of the spirit world and allow for the possibility of possession and exorcism, but resent the reduction of these events to mere medical phenomena. Others believe only in what can be proved by their own experience and are unnerved by the idea of spirit influence. He used modern day anecdotes and biblical passages to show how threatened men feel when either of these 'world views' is challenged. This diversity of opinion within the Church remains up to the present day.

The Venerable Michael Perry, Archdeacon of Durham, speculated on whether an entity could invade an individual psyche. It was clear that human minds could be influenced to a profound degree by other men, as exemplified by the followers of Hitler and the Reverend Moon. The resulting control may be as complete as if the individual was actually possessed.

Mediums and channellers appear to be able to act as vessels for other entities. There is debate as to whether the spirits and higher beings summoned by these people are in fact external powers, or repressed elements of their own personalities which surface in an altered state of consciousness. Modern psychiatry finds an explanation of multiple personality states from within an individual rather than requiring the idea of possession from outside. Similarly, those people claiming to be possessed after tampering with an ouija board may in fact be experiencing an unacceptable aspect of their own personalities projected outwards. This 'evil', previously repressed into the unconscious, appears too abhorrent to be acknowledged as belonging to 'self' and so is experienced as an alien force.

To believe in possession by demons, one must believe that within creation there is a God who exerts a physical influence on earth, and that the same creation encompasses evil, with a similar capacity to declare an earthly presence. The Venerable Perry's own beliefs allowed for the possibility of possession, but he felt that the Church needed to work alongside medical and social agencies in dealing with it. He saw the work of the exorcist as not only casting out demons, but also filling the ensuing vacuum with pastoral counselling and support.

The Reverend John Foskett, Chaplain at The Bethlem Royal and Maudsley Hospitals, examined the difference between mystical experience and religious psychosis. He suggested that many differences are created by the various perspectives from which professionals approach the subject and he invited the audience to take part in role playing, using a hypothetical case of an alleged possession. The practical management of the situation seemed to be more important than an esoteric debate as to the reality of possession or otherwise. There seemed to be a case for the involvement of clergymen, doctors and other professionals in such a situation, each bringing a different but complementary perspective to the problem.

Two aspects of possession from psychiatric viewpoints were presented. Dr David McDonald, Consultant Psychiatrist at Borocourt Hospital, Berkshire, spoke of his work in psychotherapy with a Christian background. He commented on the common use of religious language in mental illness, including expressions of being 'possessed' by inner feelings or forces. He compared the splitting of good and bad in early psycho-dynamic development with the religious concept of good and evil, God and Devil. He suggested that psychotherapy 'cast out' psychic 'demons' to their correct place in an individual being.

The Reverend Doctor Tom Grant spoke of his views of possession as both a psychiatrist and a Minister. He was concerned that theologians and physicians did not always speak the same language. As a doctor he saw events in terms of symptoms and diseases. He was careful not to take the experience of possession at face value, often finding it used as an expression of extreme disturbance with a sense of being out of control. He cited descriptions of possessed states in the Bible which appeared to correspond to epilepsy, delirium, hysteria and schizophrenia. Even in 20th century Britain, Reverend Doctor Grant had heard clear psychiatric disorder explained in terms of possession by evil spirits.

The conference ended with an open debate which raised the difficulties of practising psychiatry alongside those religious communities which reject psychiatric theory, and emphasised the importance of educating priests and doctors in their respective philosophies. There remained a diversity of professional perspectives and personal beliefs, but sharing them did seem to have made some progress towards a common understanding. 